\title{
Plutonium sorption and desorption behavior on bentonite
}

James D. Begg ${ }^{1}$, Mavrik Zavarin ${ }^{1}$, Scott J. Tumey ${ }^{2}$, Annie B. Kersting ${ }^{1}$

1. Glenn T. Seaborg Institute, Physical \& Life Sciences, Lawrence Livermore National Laboratory, 7000 East Avenue, Livermore, CA 94550, USA

2. Center for AMS, Physical \& Life Sciences, Lawrence Livermore National Laboratory, 7000 East Avenue, Livermore, CA 94550, USA

*Corresponding Author: +1 (925) 4223844 Begg2@1lnl.gov 


\section{Disclaimer}

2 This document was prepared as an account of work sponsored by an agency of the United States 3 government. Neither the United States government nor Lawrence Livermore National Security, LLC, nor 4 any of their employees makes any warranty, expressed or implied, or assumes any legal liability or 5 responsibility for the accuracy, completeness, or usefulness of any information, apparatus, product, or

6 process disclosed, or represents that its use would not infringe privately owned rights. Reference herein to 7 any specific commercial product, process, or service by trade name, trademark, manufacturer, or 8 otherwise does not necessarily constitute or imply its endorsement, recommendation, or favoring by the 9 United States government or Lawrence Livermore National Security, LLC. The views and opinions of 10 authors expressed herein do not necessarily state or reflect those of the United States government or 11 Lawrence Livermore National Security, LLC, and shall not be used for advertising or product 12 endorsement purposes.

13 LLNL-JRNL-662021 


\section{Plutonium sorption and desorption behavior on bentonite}

\section{ABSTRACT}

Understanding plutonium $(\mathrm{Pu})$ sorption to, and desorption from, mineral phases is key to understanding its subsurface transport. In this work we study $\mathrm{Pu}(\mathrm{IV})$ sorption to industrial grade FEBEX bentonite over the concentration range $10^{-7}-10^{-16} \mathrm{M}$ to determine if sorption at typical environmental concentrations $\left(\leq 10^{-12} \mathrm{M}\right)$ is the same as sorption at $\mathrm{Pu}$ concentrations used in most laboratory experiments $\left(10^{-7}-10^{-11} \mathrm{M}\right)$. $\mathrm{Pu}(\mathrm{IV})$ sorption was broadly linear over the $10^{-7}-10^{-}$ ${ }^{16} \mathrm{M}$ concentration range during the $120 \mathrm{~d}$ experimental period; however, it took up to $100 \mathrm{~d}$ to reach sorption equilibrium. At concentrations $\geq 10^{-8} \mathrm{M}$, sorption was likely affected by additional $\mathrm{Pu}(\mathrm{IV})$ precipitation/polymerization reactions. The extent of sorption was similar to that previously reported for $\mathrm{Pu}(\mathrm{IV})$ sorption to $\mathrm{SWy}-1 \mathrm{Na}-\mathrm{montmorillonite} \mathrm{over} \mathrm{a} \mathrm{narrower} \mathrm{range} \mathrm{of}$ Pu concentrations $\left(10^{-11}-10^{-7} \mathrm{M}\right)$. Sorption experiments with FEBEX bentonite and $\mathrm{Pu}(\mathrm{V})$ were also performed across a concentration range of $10^{-11}-10^{-7} \mathrm{M}$ and over a 10 month period which allowed us to estimate the slow apparent rates of $\mathrm{Pu}(\mathrm{V})$ reduction on a smectite-rich clay. Finally, a flow cell experiment with Pu(IV) loaded on FEBEX bentonite demonstrated continued desorption of Pu over a 12 day flow period. Comparison with a desorption experiment performed with SWy-1 montmorillonite showed a strong similarity and suggested the importance of montorillonite phases in controlling Pu sorption/desorption reactions on FEBEX bentonite.

KEYWORDS Plutonium; sorption; desorption; bentonite; montmorillonite; clay 


\section{1. INTRODUCTION}

Permanent interment in a deep geological repository is seen as the most viable option for radioactive waste disposal in many countries with a civilian nuclear fuel program (IAEA, 1995).

50 Conceptually, the repository scenario comprises a geological barrier (host rock) combined with

51 engineering barriers that aim to contain the radionuclides until they have decayed below harmful

52 levels. The waste itself will likely be contained in steel canisters surrounded by a layer of 53 compacted clay. The efficacy of this disposal option is related to its capacity to confine 54 radioactivity and isolate it from the biosphere (Dozol et al., 1993).

55 Due to its swelling properties, plasticity, ion exchange and sorption behavior, and sealing 56 capability, bentonite is considered a good candidate for backfill material (Guven, 1990). 57 Traditionally, the term bentonite refers to aluminum phyllosilicate clays derived from the 58 devitrification and chemical alteration of glassy volcanic ash or tuff (Ross and Shannon, 1926). 59 However, the term has been used to describe smectite-rich materials, regardless of origin (Grim, 60 1968). The smectite mineral group includes a number of 2:1 layer silicates, the most common of 61 which is montmorillonite. Montmorillonites constitute a large proportion of bentonite 62 mineralogy (65-90 wt \%) with the result that the two names are often used synonymously, 63 although the former is a clay mineral and the latter a clay rock (Grauer, 1986). Montmorillonite 64 can display significant morphological and chemical differences depending on its provenance 65 (Guven, 1988).

ENRESA, the body responsible for the management of Spanish radioactive waste, has 67 proposed FEBEX bentonite from Cortijo de Archidona in Almeria, Spain for use in its 68 repositories. As a result, the physiochemical properties of this clay rock have been well studied, 69 particularly in an extensive experimental program performed at the National Cooperative for the 
71 bentonite has a high smectite content $(93 \pm 2 \%)$ with minor quartz $(2 \pm 1 \%)$, plagioclase $(3 \pm 1$

$72 \%)$, cristobalite $(2 \pm 1 \%)$, potassium feldspar, calcite and tridymite as accessory minerals

73 (Missana et al., 2004). The less than $2 \mu \mathrm{m}$ fraction (after Ca homoionization) of this bentonite is

74 composed of $>99 \%$ smectite with the structural formula:

$75\left(\mathrm{Si}_{7.78} \mathrm{Al}_{0.22}\right)\left(\mathrm{Al}_{2.78} \mathrm{Fe}^{3+}{ }_{0.33} \mathrm{Fe}^{2+}{ }_{0.02} \mathrm{Ti}_{0.02} \mathrm{Mg}_{0.81}\right) \mathrm{O}_{20}(\mathrm{OH})_{4}\left(\mathrm{Ca}_{0.50} \mathrm{Na}_{0.08} \mathrm{~K}_{0.11}\right) \quad$ (Fernandez et al., 76 2004).

77 Due to their long half-lives and toxicity, the isotopes ${ }^{239} \mathrm{Pu}\left(2.41 \times 10^{4} \mathrm{y}\right)$ and ${ }^{240} \mathrm{Pu}(6.56 \times$ $7810^{3}$ y) are expected to contribute significantly to the total hazardous inventory in a waste 79 repository scenario (Schwenk-Ferrero, 2013). Despite several decades of study, our 80 understanding of how $\mathrm{Pu}$ migrates in subsurface environments is far from complete due to the 81 wide array of factors which can significantly influence its mobility. These include $\mathrm{Pu}$ redox 82 processes (Choppin, 1991; Sanchez et al., 1985), colloid-facilitated transport processes (Kersting 83 et al., 1999; Novikov et al., 2006), solubility effects (Efurd et al., 1998; Neck et al., 2007), 84 sorption/desorption rates and affinities for natural mineral surfaces (Powell et al., 2004; Zavarin 85 et al., 2012), and interactions with natural organic matter (including bacteria) (Icopini et al., 86 2009; Zhao et al., 2011). Pu exhibits a complex redox chemistry in natural waters with four 87 oxidation states (VI, V, IV, III) potentially stable and with each oxidation state displaying a 88 unique solubility (Neck et al., 2007) and mineral sorption affinity (Begg et al., 2013; Keeney89 Kennicutt and Morse, 1985; Sanchez et al., 1985; Silva and Nitsche, 1995). Pu(IV) and Pu(V) 90 are the more common species under mildly oxic environmental conditions and also represent the 91 oxidation states with the lowest $(\mathrm{Pu}(\mathrm{V}))$ and highest $(\mathrm{Pu}(\mathrm{IV}))$ affinities for mineral surfaces 92 (Choppin, 2007; Kaplan et al., 2007; Silva and Nitsche, 1995). 
Mineral-colloid facilitated transport is thought to be a significant contributor to $\mathrm{Pu}$ migration

94 in the subsurface (Kersting et al., 1999; Novikov et al., 2006; Santschi et al., 2002). One of the

95 concerns with the use of bentonite as a backfill material in a repository is that it can form

96 colloids, which may enhance the migration of radionuclide species that are sorbed to them

97 (Geckeis et al., 2004). As a result, attention has been focused on the interaction between $\mathrm{Pu}$ and

98 bentonite colloids (Huber et al., 2011; Missana et al., 2008). Previous work on FEBEX bentonite

99 has shown that colloids with a hydrodynamic size of $250 \pm 50 \mathrm{~nm}$ have an XRD pattern

100 consistent with an aluminum-rich dioctahedral smectite with no significant impurities (Missana

101 et al., 2004).

102 The sorption of $\mathrm{Pu}$ species to Khakassiya bentonite and SWy-1 montmorillonite has been

103 found to exhibit $\mathrm{pH}$ and ionic strength dependency, indicating that both ion-exchange and 104 surface complexation processes are occurring (Sabodina et al., 2006; Zavarin et al., 2012). 105 However, surface complexation processes will dominate at neutral to alkaline pHs. Smectite 106 minerals have been shown to have a high sorption affinity for $\mathrm{Pu}$. For example, $\mathrm{Pu}(\mathrm{V})$ 107 partitioning to Yucca Mountain tuffs found a ubiquitous and preferential association of $\mathrm{Pu}$ with 108 smectite minerals (Vaniman et al., 1995). Further, $\mathrm{Pu}(\mathrm{IV}) \mathrm{K}_{\mathrm{d}}$ values from 10,000 to $40,000 \mathrm{~L} \mathrm{~kg}^{-}$

$109{ }^{1}\left(\log \mathrm{K}_{\mathrm{d}} 4.0\right.$ to 4.6$)$ have been reported for smectite-rich sediments from Lithuania in the $\mathrm{pH}$ 110 range 5 to 12 (Lujaniene et al., 2007). Missana et al. (2008) studied the sorption of Pu(IV) to 111 FEBEX bentonite colloids (>99\% smectite) at $\mathrm{pH} 9.5$ and reported $\log \mathrm{K}_{\mathrm{d}}$ values of $5.37 \pm 0.18$.

$112 \mathrm{Pu}(\mathrm{IV})$ sorption to FEBEX bentonite colloids under anaerobic conditions at $\mathrm{pH} 9.6$, resulted in $113 \log \mathrm{R}_{\mathrm{d}}$ values (a term equivalent to $\mathrm{K}_{\mathrm{d}}$ but without the assumption of equilibrium) of 5 and 5.9 114 after one and three weeks of sorption time, respectively (NAGRA, 2006). The increase in $R_{d}$ 
115 values with time was attributed to the presence of a small amount $(\sim 5 \%)$ of $\mathrm{Pu}(\mathrm{VI})$ in the spike

116 solution which was slowly reduced to $\mathrm{Pu}(\mathrm{IV})$ on the mineral surface (NAGRA, 2006).

117 In a recent study, we examined the long term sorption behavior of $\mathrm{Pu}(\mathrm{IV})$ and $\mathrm{Pu}(\mathrm{V})$ on 118 SWy-1 Na-montmorillonite under aerobic conditions. After 30 d equilibration, calculated $\log \mathrm{K}_{\mathrm{d}}$ 119 values for $\mathrm{Pu}(\mathrm{IV})$ and $\mathrm{Pu}(\mathrm{V})$ were $4.25 \pm 0.15$ and $3.57 \pm 0.18$, respectively (Begg et al., 2013). 120 However, following one year of equilibration, calculated $\log \mathrm{K}_{\mathrm{d}}$ values in the $\mathrm{Pu}(\mathrm{V})$ experiments 121 had increased to $4.32 \pm 0.15$, similar to those calculated for $\mathrm{Pu}(\mathrm{IV})$ after $30 \mathrm{~d}$. The convergence 122 of $\mathrm{K}_{\mathrm{d}}$ values for $\mathrm{Pu}(\mathrm{IV})$ and $\mathrm{Pu}(\mathrm{V})$ was attributed to the slow reduction of $\mathrm{Pu}(\mathrm{V})$ on the 123 montmorillonite surface causing increased uptake of $\mathrm{Pu}(\mathrm{V})$. This finding highlights the need to 124 ensure that experimental studies used to inform predictive transport models accurately 125 encapsulate long term environmental behaviors.

Several recent studies have indicated that actinide concentration can affect their sorption to 127 mineral surfaces (Hixon and Powell, 2014; Missana et al., 2008; Snow et al., 2013). In the case 128 of $\mathrm{Pu}(\mathrm{IV})$, its low solubility at circumneutral $\mathrm{pH}$ means that sorption may demonstrate an 129 apparent concentration dependence as solubility limits are reached. For example, the study of $130 \mathrm{Pu}(\mathrm{IV})$ sorption to bentonite colloids (>99\% smectite) showed that sorption was linear for initial $131 \mathrm{Pu}$ concentrations of $1 \times 10^{-8}-1 \times 10^{-7} \mathrm{M}$ but at higher concentrations precipitation of $\mathrm{Pu}$ was 132 evidenced by a sharp increase in the isotherm slope (Missana et al., 2008). Concentration 133 dependent sorption behavior may also be observed at low actinide concentrations: work with 134 goethite and $\mathrm{Np}(\mathrm{V})$ found that $\mathrm{K}_{\mathrm{d}}$ values differed by an order of magnitude at solution 135 concentrations below $10^{-11} \mathrm{M}$ compared to higher concentrations (Snow et al., 2013). This 136 behavior was attributed to the existence of different adsorption sites on the mineral having 137 different adsorption affinities for $\mathrm{Np}$. These examples of concentration dependent behavior of 
138 actinides indicate that there may be a difference between the sorption behavior of $\mathrm{Pu}$ at the 139 concentrations found in contaminated subsurface waters $\left(10^{-12}-10^{-20} \mathrm{M}\right)$ (Dai et al., 2005;

140 Kersting et al., 1999; Novikov et al., 2006; Penrose et al., 1990) and concentrations typically 141 used in laboratory experiments $\left(10^{-7}-10^{-11} \mathrm{M} \mathrm{Pu}\right)$. Although a primary assumption of reactive 142 transport models, the validity of extrapolating Pu-mineral sorption behavior from relatively high 143 concentration laboratory experiments to the low concentrations found in many field settings has 144 not been widely tested.

$145 \mathrm{Pu}$ desorption reactions have been far less well studied than sorption reactions. This is 146 problematic because application of thermodynamic equilibrium parameters in field transport 147 models which incorrectly represent desorption processes are likely to be flawed (Artinger et al., 148 2002). One of the pertinent issues for $\mathrm{Pu}$, especially given the evidence that its mobility may be 149 enhanced by mineral-colloid facilitated transport, is whether there is equality in sorption and 150 desorption behavior (Kersting et al., 1999). Differences in behavior may be caused by aging 151 processes, hysteresis effects, and irreversible sorption, amongst others (Tinnacher et al., 2011). A 152 study of $\mathrm{Pu}(\mathrm{IV})$ sorption to Callovo-Oxfordian argillite found that after seven days' desorption, $153 \mathrm{Pu} \mathrm{K}$ values were of the same order of magnitude as they were following a seventy four day 154 adsorption period, indicating sorption reversibility (Latrille et al., 2006). Similarly, Lu et al. 155 (2003) investigated $\mathrm{Pu}$ interaction with montmorillonite and found that with a 20 day adsorption 156 period and a 32 day desorption period, similar $\mathrm{K}_{\mathrm{d}}$ values were obtained for both adsorption and 157 desorption steps.

158 The aim of the current work is two-fold: to provide information on Pu sorption/desorption 159 to/from industrial grade FEBEX bentonite, a potential repository backfill material, and to 160 determine if the linearity observed for $\mathrm{Pu}(\mathrm{V})$ sorption to a pure Na-montmorillonite (Begg et al., 
1612013 ) extends to $\mathrm{Pu}(\mathrm{IV})$ sorption to a multi-component clay rock material. We investigate the 162 sorption behavior of $\mathrm{Pu}(\mathrm{IV})$ to FEBEX bentonite across a wide range of initial concentrations $163\left(10^{-7}-10^{-16} \mathrm{M}\right)$ over a $120 \mathrm{~d}$ period. In addition, we perform long term (10 month) sorption 164 experiments with $\mathrm{Pu}(\mathrm{V})$ to compare with the slow apparent rates of reduction previously 165 observed for $\mathrm{Pu}(\mathrm{V})$ on montmorillonite (Begg et al., 2013). The results of these experiments 166 demonstrate the apparent control that the montmorillonite component in bentonite exerts on the 167 sorption behavior of $\mathrm{Pu}$, provides long term sorption data for industrial grade FEBEX bentonite, 168 and validates the extrapolation of $\mathrm{Pu}(\mathrm{IV})$ experiments performed at concentrations of $10^{-9}-10^{-11}$ $169 \mathrm{M}$ Pu to much lower concentrations typically found in the environment at timescales relevant for 170 groundwater transport.

\section{2. MATERIALS AND METHODS}

\subsection{Bentonite Preparation}

Unless stated otherwise, all solutions were prepared using ultrapure water (Milli-Q Gradient

174 System, >18 M $\Omega \cdot \mathrm{cm}$ ) and ACS grade chemicals without further purification. The FEBEX 175 bentonite was ground in a mortar and pestle and sieved to $<63 \mu \mathrm{m}$ to minimize clay 176 heterogeneity. The clay was then homo-ionized in $1 \mathrm{M} \mathrm{NaCl}$ solution for 7 days and dialyzed in $177 \mathrm{MQ} \mathrm{H}_{2} \mathrm{O}$ to remove excess salts. As experiments were performed to characterize the behavior of $178 \mathrm{Pu}$ in the presence of bulk bentonite, no further treatment was performed. A portion of the 179 bentonite suspension was dried, the clay lightly ground, and its surface area measured $\left(\mathrm{N}_{2}(\mathrm{~g})\right.$ 180 BET Quadrasorb SI). The surface area of the prepared bentonite was $25.2 \pm 1.0 \mathrm{~m}^{2} \mathrm{~g}^{-1}$.

181 The solids were re-suspended in a $0.7 \mathrm{mM} \mathrm{NaHCO}_{3}, 5 \mathrm{mM} \mathrm{NaCl}$ buffer solution (pH 8) to 182 make a suspension with a bentonite concentration of $\sim 5 \mathrm{~g} \mathrm{~L}^{-1}$. This buffer solution was chosen 183 so as to allow comparison with previous experiments performed with SWy-1 Na- 
184 montmorillonite (Begg et al., 2013). Gravimetric analysis of the dried mass of the solid in 185 triplicate $5 \mathrm{~mL}$ aliquots of the suspension returned a standard error of $1.2 \%$, indicating 186 homogeneity in the stock suspension and providing confidence in the amount of solid added to 187 experiments. The stock suspension was allowed to equilibrate under aerobic conditions for 188 several days prior to the start of sorption experiments.

\subsection{Pu Stock Solutions}

190

191

192

193

194

195

196

197

198

199

200

201

202

203

204

205

206

Three different $\mathrm{Pu}$ stock solutions were used in the sorption experiments in order to facilitate measurement over the wide range of $\mathrm{Pu}$ concentrations investigated. $\mathrm{A}{ }^{242} \mathrm{Pu}$ stock $\left(15.8 \%{ }^{238} \mathrm{Pu}\right.$, $5.1 \%{ }^{239+240} \mathrm{Pu}, 79.1 \%{ }^{242} \mathrm{Pu}$ by activity) and a ${ }^{238} \mathrm{Pu}$ stock $\left(98.8 \%{ }^{238} \mathrm{Pu}, 0.11 \%{ }^{241} \mathrm{Pu}\right.$, and $0.1 \%$ ${ }^{239} \mathrm{Pu}$ by activity) were used in experiments with initial concentrations of $10^{-7}-10^{-11} \mathrm{M}$. A New Brunswick Laboratory (NBL) Pu reference material CRM-137 $\left(33.5 \%{ }^{238} \mathrm{Pu}, 35.3 \%{ }^{239} \mathrm{Pu}, 31.3 \%\right.$ ${ }^{240} \mathrm{Pu}$ by activity) was used in experiments with initial $\mathrm{Pu}$ concentrations $\leq 10^{-11} \mathrm{M}$. A table of the different stocks used, including their oxidation state, where measured, is given in Supplementary information Table S1.

The Pu stock solutions were purified using anion exchange resin (BioRad AG $1 \times 8,100-200$ mesh) pre-conditioned with $8 \mathrm{M} \mathrm{HNO}_{3}$. Prior to loading on the resin, $\mathrm{Pu}$ was reacted with $\mathrm{NaNO}_{2}$ to reduce it to $\mathrm{Pu}(\mathrm{IV})$. The $\mathrm{Pu}$ was loaded on the resin in $8 \mathrm{M} \mathrm{HNO}_{3}$, washed with 3 column volumes of $8 \mathrm{M} \mathrm{HNO}_{3}$, and then eluted in $1 \mathrm{M}$ or $0.1 \mathrm{M} \mathrm{HCl}$ (Powell et al., 2011a). For experiments using $\mathrm{Pu}(\mathrm{IV})$, the oxidation state of the $\mathrm{Pu}$ stocks was checked with a $\mathrm{LaF}_{3}$ precipitation method (Kobashi and Choppin, 1988) and found to be at least $\geq 92 \% \mathrm{Pu}(\mathrm{III}) /(\mathrm{IV})$ (Table S1). Subsequent stock dilutions were made using $0.1 \mathrm{M} \mathrm{HCl,} \mathrm{with} \mathrm{select} \mathrm{analysis}$ indicating that this did not significantly alter the oxidation state of the $\mathrm{Pu}$. For experiments starting with $\mathrm{Pu}(\mathrm{V})$, the $\mathrm{Pu}(\mathrm{IV})$ stripped from the columns was converted to $\mathrm{Pu}(\mathrm{VI})$ either 
207 electrochemically $\left({ }^{242} \mathrm{Pu}\right.$ stocks $)$ or by heating in $\mathrm{HNO}_{3}\left({ }^{238} \mathrm{Pu}\right.$ stocks $)$, adjusting to $\mathrm{pH} 3$ with

$208 \mathrm{NaOH}$, spiking with $0.05 \mathrm{M}$ hydrogen peroxide and gently heating to produce $\mathrm{Pu}(\mathrm{V})$. To remove 209 any $\mathrm{Pu}(\mathrm{VI})$ remaining in solution, the stocks were diluted in $0.7 \mathrm{mM} \mathrm{NaHCO} 3,5 \mathrm{mM} \mathrm{NaCl}$

210 buffer solution to achieve a circumneutral $\mathrm{pH}$ and contacted with $10 \mathrm{~g} / \mathrm{L}$ high surface area $\mathrm{SiO}_{2}$,

211 which will preferentially adsorb $\mathrm{Pu}(\mathrm{VI})$, before being phase separated for use in experiments

212 (Orlandini et al., 1986). $\mathrm{Pu}(\mathrm{V})$ stocks were $<3 \% \mathrm{Pu}(\mathrm{III}) /(\mathrm{IV})$ by $\mathrm{LaF}_{3}$ precipitation. Final $\mathrm{Pu}$

213 concentration in the stock solutions was determined by liquid scintillation counting (LSC;

214 Packard Tri-Carb TR2900 LSA and Ultima Gold cocktail).

\section{$215 \quad 2.3$ Plutonium Batch Sorption Experiments}

216 Sorption experiments were performed over a wide range of initial $\mathrm{Pu}(\mathrm{IV})$ concentrations $\left(10^{-7}\right.$

$\left.217-10^{-16} \mathrm{M}\right)$. In the following description we use the nominal terms high concentration to refer to 218 experiments initially spiked to $\mathrm{Pu}$ concentrations of $10^{-7}-10^{-11} \mathrm{M}$ and low concentration for 219 experiments initially spiked to $\mathrm{Pu}$ concentrations of $10^{-11}-10^{-16} \mathrm{M}$. The two types of 220 experiments were performed in separate laboratories in order to minimize any potential 221 contamination of the low concentration samples.

$222 \mathrm{All} \mathrm{Pu}(\mathrm{IV})$ and $\mathrm{Pu}(\mathrm{V})$ batch sorption experiments were performed under air in $0.7 \mathrm{mM}$ $223 \mathrm{NaHCO}_{3}, 5 \mathrm{mM} \mathrm{NaCl}$ buffer solution (pH 8) with $1 \mathrm{~g} \mathrm{~L}^{-1}$ FEBEX bentonite. These experimental 224 conditions were chosen to achieve consistency with previous experiments using SWy-1 Na225 montmorillonite (Begg et al., 2013). $\mathrm{Pu}(\mathrm{IV})$ and $\mathrm{Pu}(\mathrm{V})$ aqueous speciation for initial $\mathrm{Pu}$ 226 concentrations of $10^{-10} \mathrm{M}$ in the buffer solution were calculated using the Geochemist's 227 Workbench family of codes and thermodynamic data from Guillaumont et al. (2003). The results 228 are shown in Supplementary Information (SI) Figure S1. Batch experiments were conducted in 229 either $50 \mathrm{~mL}$ Nalgene Oak Ridge polycarbonate centrifuge tubes (high concentration) or $500 \mathrm{~mL}$ 
230 Nalgene bottles (low concentration). Higher volumes were required in low concentration

231 experiments to achieve the low detection limits afforded by accelerator mass spectrometry

232 (AMS). $\mathrm{Pu}(\mathrm{IV})$ sorption experiments were performed at low concentrations and high

233 concentrations, while $\mathrm{Pu}(\mathrm{V})$ experiments were performed only at high concentrations. For

$234 \mathrm{Pu}(\mathrm{IV})$ experiments, where the $\mathrm{Pu}$ stock was in $0.1 \mathrm{M} \mathrm{HCl}$, dilute $\mathrm{NaOH}$ was added to the

235 samples immediately prior to spiking in order to neutralize the acidity associated with the $\mathrm{Pu}(\mathrm{IV})$

236 spike. This was not necessary for $\mathrm{Pu}(\mathrm{V})$ experiments where the $\mathrm{pH}$ of the stock was

237 circumneutral. Bentonite blanks (with no $\mathrm{Pu}$ ) and $\mathrm{Pu}$ spiked blanks (with no bentonite; select

238 concentrations) were run in parallel. The results of the mineral free experiments are included in

239 the SI. The $\mathrm{pH}$ of each experiment was checked (Orion 920A with calibrated electrode) and

240 adjusted to $\mathrm{pH} 8.0 \pm 0.2$ using dilute $\mathrm{NaOH}$ or $\mathrm{HCl}$ within 10 minutes of spiking. Measurement

241 of $\mathrm{pH}$ over the course of the experiments indicated that the drift in $\mathrm{pH}$ was less than $0.2 \mathrm{pH}$ units.

242 Samples were placed on an orbital shaker at $125 \mathrm{rpm}$ at room temperature for the duration of the

243 experiment. Experiments were kept in the dark in order to minimize photo-catalyzed reactions

244 that may directly or indirectly affect the redox speciation of Pu (McCubbin and Leonard, 1996;

245 Powell et al., 2005).

246 At each time point, samples were centrifuged to achieve a $50 \mathrm{~nm}$ size cut off. No further 247 attempts at size fractionation were made. We note that centrifugation can potentially remove not 248 only Pu sorbed on bentonite but also any Pu precipitates with a particle size greater than $50 \mathrm{~nm}$. 249 Thus, the apparent sorption determined based on centrifugation could, in fact, represent a 250 combination of $\mathrm{Pu}$ sorption, $\mathrm{Pu}$ precipitation, as well as $\mathrm{Pu}$ surface precipitation on the bentonite 251 particle surfaces. However, in the low concentration experiments, we consider the formation of $252 \mathrm{Pu}$ precipitates and/or polynuclear species to be thermodynamically unfavorable. For high 
253 concentration samples, aliquots of both the suspension and the supernatant were removed and

254 counted via LSC. In low concentration experiments, aliquots of supernatant were acidified to $2 \%$

$255 \mathrm{HNO}_{3}$ and analyzed using AMS (10-MeV tandem accelerator at the Center for Accelerator Mass

256 Spectrometry (CAMS), Lawrence Livermore National Laboratory, CA). AMS is an ultra-

257 sensitive analytical technique that can quantify long-lived radionuclides at ultra-low

258 concentrations and routinely achieves instrumental backgrounds of $10^{5}$ atoms for actinide

259 elements (Marchetti et al., 2005). AMS analysis has been reported previously and included

260 isotope dilution using a non-isobarically interfering isotope of ${ }^{242} \mathrm{Pu}\left(99.99 \%{ }^{242} \mathrm{Pu}\right)(\mathrm{Marchetti}$ et

261 al., 2005).

\subsection{Plutonium Desorption Flow Cell Experiments}

A stirred flow cell experiment was performed at $\mathrm{pH} 8$ to examine the desorption of $\mathrm{Pu}(\mathrm{IV})$

264 from bentonite. The flow cell set up was similar to that described previously for $\mathrm{Np}(\mathrm{V})$ and 265 goethite and $\mathrm{Pu}(\mathrm{IV})$ and goethite (Begg et al., 2014; Tinnacher et al., 2011). The flow cell was 266 made of Teflon ${ }^{\circledR}$, with a $20 \mathrm{~mL}$ hemispherical chamber and fitted with a $100 \mathrm{~nm}$ pore size

267 Millipore polycarbonate filter. A diagram of the flow cell is shown in SI Figure S2. Prior to use,

268 the cell was washed with $10 \% \mathrm{HCl}$ and MQ water. To sorb $\mathrm{Pu}$ on the clay, $\mathrm{Pu}(\mathrm{IV})$ at $3 \times 10^{-10} \mathrm{M}$

269 was equilibrated with $1 \mathrm{~g} \mathrm{~L}^{-1}$ bentonite for 21 days. After this equilibration period, an aliquot of 270 the spiked suspension was centrifuged $(25000 \times g, 2 \mathrm{~h} ; 50 \mathrm{~nm}$ cut-off $)$ and the concentration of 271 the $\mathrm{Pu}$ in the supernatant measured. A $20 \mathrm{~mL}$ aliquot of bentonite suspension was loaded into the 272 flow cell with a stir bar included to ensure ideal mixing conditions. In previous flow cell work 273 with SWy-1 Na-montmorillonite, ${ }^{3} \mathrm{H}$ was used as a conservative tracer to test if ideal mixing 274 conditions existed. A plot of the decline in ${ }^{3} \mathrm{H}$ concentration and a theoretical non-reactive 
275 species is shown in SI Figure S3. The similarity between the calculated and observed curves

276 demonstrates that the flow cell experiment is ideally mixed when the stir bar is operational.

277 Atmosphere-equilibrated, $\mathrm{Pu}$ free, $0.7 \mathrm{mM} \mathrm{NaHCO}_{3}, 5 \mathrm{mM} \mathrm{NaCl}$ buffer solution at pH 8 was

278 flowed through the cell at an initial rate of $0.4 \mathrm{~mL} \mathrm{~min}^{-1}$ (average retention time of $\sim 50$

279 minutes). Effluent fractions were collected on a Spectra/Chrom CF-1 fraction collector and the

280 volumes determined gravimetrically. Periodic $\mathrm{pH}$ measurements of the effluent were performed

281 to ensure that the experiment remained at $\mathrm{pH}$ 8. Collected fractions were acidified with $2 \%$

$282 \mathrm{HNO}_{3}$ prior to $\mathrm{Pu}$ analysis. $\mathrm{Pu}$ concentration in the effluent fractions was determined via liquid

283 scintillation counting. The total timescale of the flow cell experiment was 12 days.

\section{3. RESULTS AND DISCUSSION}

$2853.1 \mathrm{Pu}(\mathrm{IV})$ Sorption to Bentonite

286 The sorption of $\mathrm{Pu}(\mathrm{IV})$ to bentonite was studied over an initial $\mathrm{Pu}$ concentration range of $10^{-7}$

$287-10^{-16} \mathrm{M}$. The resulting sorption isotherm after $120 \mathrm{~d}$ equilibration is shown in Figure 1. To 288 determine if sorption equilibrium was achieved in the experiment, samples at $10^{-10}$ and $10^{-7} \mathrm{M}$

289 were sampled after $67 \mathrm{~d}, 100 \mathrm{~d}$ and $120 \mathrm{~d}$. The results of this sampling are shown in the inset in

290 Figure 1. The similarity in the aqueous $\mathrm{Pu}$ concentrations at $100 \mathrm{~d}$ and $120 \mathrm{~d}$ versus $67 \mathrm{~d}$

291 indicate that sorption equilibrium was reached by $120 \mathrm{~d}$. The slow approach to sorption 292 equilibrium is consistent with previous studies on $\mathrm{Pu}(\mathrm{IV})$ sorption to clay and may reflect the 293 presence of small amounts of $\mathrm{Pu}(\mathrm{V})$ in the initial stock solution, although we cannot discount 294 other aging processes such as $\mathrm{Pu}$ polymerization/precipitation reactions, particularly in the higher 295 concentration sample (Begg et al., 2013; NAGRA, 2006). Sorption of pure Pu(IV) to bentonite 296 should be followed by oxidation of some fraction of $\mathrm{Pu}(\mathrm{IV})$ and a decrease in $\mathrm{Kd}$ over time. 297 However, the presence of $\mathrm{Pu}(\mathrm{V})$ in the $\mathrm{Pu}(\mathrm{IV})$ spike masked any decrease in $\mathrm{Kd}$ as a function 
298 time due to $\mathrm{Pu}(\mathrm{IV})$ oxidation. A similar observation was made by (Powell et al., 2011b) for $299 \mathrm{Pu}(\mathrm{IV})$ sorption to montmorillonite. Moreover, unintended changes in $\mathrm{Pu}$ oxidation state may be exacerbated when an acidic $\mathrm{Pu}(\mathrm{IV})$ stock is spiked into a circumneutral $\mathrm{pH}$ solution under oxic 301 conditions. In the supplemental information, Figure S4 shows oxidation state analysis of a 302 parallel experiment where a mineral-free, $\mathrm{pH} 8$ solution was spiked with a >97\% $\mathrm{Pu}(\mathrm{III}) /(\mathrm{IV})$ 303 stock solution $\left(4.48 \times 10^{-7} \mathrm{M}\right)$ to a concentration of $3 \times 10^{-10} \mathrm{M}$. Both $\mathrm{LaF}_{3}$ and solvent 304 extraction analysis of the aqueous $\mathrm{Pu}$ indicate that $1 \mathrm{~h}$ after spiking, approximately $30 \%$ of the $305 \mathrm{Pu}(\mathrm{III}) /(\mathrm{IV})$ had been oxidized to $\mathrm{Pu}(\mathrm{V}) /(\mathrm{VI}) . \mathrm{LaF}_{3}$ analysis over $6 \mathrm{~d}$ showed no appreciable 306 change in $\mathrm{Pu}$ oxidation state from the $1 \mathrm{~h}$ values while no significant $\mathrm{Pu}$ was lost from solution 307 over this short time period. orders of magnitude concentration range tested (Figure 1). Our results show that on timescales of 310 months, $\mathrm{Pu}(\mathrm{IV})$ exhibits similar apparent sorption behavior to bentonite at the higher 311 concentrations used in typical laboratory experiments $\left(10^{-7}-10^{-11} \mathrm{M}\right)$ as it does at concentrations 312 typically found in contaminated environments $\left(\leq 10^{-12} \mathrm{M}\right)$. This result complements previously 313 published linear sorption behavior observed for $\mathrm{Pu}(\mathrm{V})$ on $\mathrm{SWy}-1 \mathrm{Na}$-montmorillonite over a 314 similar $\mathrm{Pu}$ concentration range (Begg et al., 2013). A log-log slope for $\mathrm{Pu}(\mathrm{IV})$ sorption to 315 bentonite was calculated and found to be $1.06 \pm 0.01$ (1 S.E.). A value greater than 1 suggests 316 that surface precipitation (or, indeed, bulk precipitation in our case) of Pu may be occurring 317 (Dzombak and Morel, 1993). The expected concentration range for $\mathrm{Pu}(\mathrm{IV})$ intrinsic colloid 318 formation at pH 8 is highlighted in blue in Figure 1 (Neck et al., 2007). Based on thermodynamic 319 considerations, the highest two concentrations used in the current isotherm experiment should 320 lead to $\mathrm{Pu}(\mathrm{IV})$ precipitation and colloid formation (Neck et al., 2007). The isotherm slope also 
321 suggests that polymerization/ surface precipitation processes may be occurring in the two highest

$322 \mathrm{Pu}$ concentration samples (initial $\mathrm{Pu}(\mathrm{IV}) 10^{-7}$ and $10^{-8} \mathrm{M}$ ). This is consistent with $\mathrm{Pu}$-goethite

323 sorption data of Kersting et al. (2011) that exhibited substantial Pu precipitation effects only

324 above $10^{-8} \mathrm{M} \mathrm{Pu}$. Although the effects of precipitation/polymerization appear to be relatively

325 small when examined across 10 orders of magnitude in Pu concentration and on a log scale, they

326 nonetheless affect the apparent sorption behavior of $\mathrm{Pu}$ at the two highest $\mathrm{Pu}$ concentration

327 samples (initial $\mathrm{Pu}(\mathrm{IV}) 10^{-7}$ and $10^{-8} \mathrm{M}$ ). Accordingly, we recommend that future experiments

328 investigating $\mathrm{Pu}(\mathrm{IV})$ environmental adsorption behavior are performed at concentrations $<10^{-9}$

329 M.

330 As the isotherm slope is close to unity, sorption can be considered Langmuirian in behavior.

331 However, unlike traditional Langmuir plots which exhibit a flattening of the isotherm as mineral

332 surface sites become saturated, the data remain largely linear at higher concentrations.

333 Previously, Missana and Garcia-Gutierrez (2007) calculated the strong site concentration on

334 bentonite colloids to be $6.1 \times 10^{-8} \mathrm{~mol} \mathrm{~m}{ }^{-2}$. Given that the experiments were performed with $1 \mathrm{~g}$

$335 \mathrm{~L}^{-1}$ clay with a surface area of $25 \mathrm{~m}^{2} \mathrm{~g}^{-1}$ this would suggest a strong site concentration of $1.54 \times$

$33610^{-6}$ mol L ${ }^{-1}$ which exceeds the highest $\mathrm{Pu}$ concentration used $\left(10^{-7} \mathrm{M}\right)$. As a result, strong site

337 saturation effects are not expected or observed in our experiments. Indeed, we suggest that

338 polymerization/precipitation/surface precipitation effects will become prominent before 339 saturation of strong sites occurs.

340 Previous work with $\mathrm{Pu}(\mathrm{IV})$ and hematite has identified a concentration dependence to the 341 rate of $\mathrm{Pu}(\mathrm{IV})$ sorption over a $2 \mathrm{~d}$ period (Romanchuk et al., 2011). A one-step, fast adsorption

342 was seen in experiments with $10^{-14} \mathrm{M} \mathrm{Pu}$ compared to a two-step adsorption (fast initial sorption

343 followed by slower uptake) at $10^{-10} \mathrm{M} \mathrm{Pu}$. The fast sorption step was attributed to the adsorption 
344 of monomeric $\mathrm{Pu}(\mathrm{IV})$ while the slower step was hypothesized to be caused either by diffusion to 345 micropores or by the formation of polymeric $\mathrm{Pu}(\mathrm{IV})$ species (Romanchuk et al., 2011). Our 346 current work with clays indicates that regardless of initial sorption rates, the apparent extent of $347 \mathrm{Pu}(\mathrm{IV})$ sorption to bentonite appears broadly independent of initial concentration for the $10^{-7}-$ $34810^{-16} \mathrm{M}$ range on timescales relevant to groundwater transport scenarios. However, there are 349 indications of $\mathrm{Pu}$ polymerization/ precipitation reactions in our highest concentration samples 350 and the importance of such reactions is acknowledged.

Log $\mathrm{K}_{\mathrm{d}}$ values from the $\mathrm{Pu}(\mathrm{IV})$ bentonite sorption isotherm at $120 \mathrm{~d}$ range from $4.3-4.9$. 352 There was a slight increase in calculated $\log \mathrm{K}_{\mathrm{d}}$ values as a function of $\mathrm{Pu}(\mathrm{IV})$ concentration. We 353 attribute this to $\mathrm{Pu}(\mathrm{IV})$ intrinsic colloid formation and/or other precipitation processes at the 354 higher concentrations, as discussed previously, rather than the result of concentration-dependent, 355 high sorption affinity sites on the clay (that would exhibit an inverse relationship between $\mathrm{K}_{\mathrm{d}}$ and $356 \mathrm{Pu}(\mathrm{IV})$ concentration). The $\log \mathrm{K}_{\mathrm{d}}$ values observed in this experiment are lower than values for $357 \mathrm{Pu}(\mathrm{IV})$ sorption to bentonite colloids of 5-5.9 measured by Geckeis et al. (2004) and 5.39 \pm 0.18 358 measured by Missana et al. (2008). However, these previous experiments were performed at $\mathrm{pH}$ $3599.5-9.6$, used bentonite colloids of $\sim 200-280 \mathrm{~nm}$ (which are expected to be entirely composed 360 of montmorillonite) and were performed under anaerobic conditions (Huber et al., 2011). The $361 \mathrm{~K}_{\mathrm{d}}$ values observed here likely reflect the contribution of $\mathrm{Pu}(\mathrm{V})$, which sorbs weakly to 362 montmorillonite and reduces slowly to $\mathrm{Pu}(\mathrm{IV})$ under aerobic conditions (Zavarin et al., 2012). 363 Anaerobic conditions expected in certain repository scenarios are likely to promote greater $364 \mathrm{Pu}(\mathrm{IV})$ stability relative to the aerobic conditions examined herein.

365 Also shown in Figure 1 is the $30 \mathrm{~d}$ sorption isotherm for $\mathrm{Pu}(\mathrm{IV})$ on SWy-1 Na366 montmorillonite previously reported in Begg et al. (2013). Comparison of the Pu(IV) sorption 
367 isotherms for montmorillonite and bentonite shows they are very similar in terms of slope and

368 the extent of $\mathrm{Pu}$ sorption. These results show that $\mathrm{Pu}$ sorption by a bulk bentonite (92\%

369 montmorillonite) is comparable to sorption to pure montmorillonite. However, a slightly higher

370 sorption affinity of $\mathrm{Pu}(\mathrm{IV})$ for bentonite than montmorillonite is observed and is more marked at

371 the two highest $\mathrm{Pu}$ concentrations. Given that the current work suggests that sorption equilibrium

372 is not achieved until after $67 \mathrm{~d}$ (Figure 1 inset), we suggest that this difference is in part due to

373 the different equilibration period in the two experiments: $30 \mathrm{~d}$ for montmorillonite and $120 \mathrm{~d}$ for

374 bentonite. Indeed, interpolation of bentonite $\mathrm{K}_{\mathrm{d}}$ values for the experiment at $10^{-10} \mathrm{M} \mathrm{Pu}(\mathrm{IV})$

375 suggests a $30 \mathrm{~d} \log \mathrm{K}_{\mathrm{d}}$ of 4.1 compared to 4.3 in the equivalent montmorillonite experiment.

$376 \quad 3.2 \mathrm{Pu}(\mathrm{V})$ Sorption to Bentonite

377 The sorption rate of $\mathrm{Pu}(\mathrm{V})$ to FEBEX bentonite was studied in triplicate over a 30 day period 378 using an initial concentration of $10^{-10} \mathrm{M}$ (Figure 2). Also plotted in Figure 2 is the sorption of $379 \mathrm{Pu}(\mathrm{V})$ to $\mathrm{SWy}-1 \mathrm{Na}-\mathrm{montmorillonite}$ at an initial concentration of $10^{-9} \mathrm{M}$ reported previously 380 (Begg et al., 2013). Both sorption plots show a similar time dependence, suggesting that the 381 montmorillonite component of the bentonite controls the sorption of $\mathrm{Pu}(\mathrm{V})$. The sorption of $382 \mathrm{Pu}(\mathrm{V})$ by bentonite shows an initial rapid uptake with $49.5 \% \pm 0.7 \%$ removed in the first $48 \mathrm{~h}$. 383 This is followed by a slower uptake over the rest of the experiment with $13.4 \pm 1.6 \% \mathrm{Pu}$ 384 remaining in solution at $30 \mathrm{~d}$. Applying the first order rate model previously used to describe $385 \mathrm{Pu}(\mathrm{V})$ sorption to $\mathrm{SWy}-1$ montmorillonite to the bentonite-Pu(V) sorption data leads to a surface 386 area normalized sorption rate of $10^{-3.5} \mathrm{~L} \mathrm{~m}^{-2} \mathrm{~h}^{-1}$ which compares quite favorably with $10^{-2.8} \mathrm{~L} \mathrm{~m}^{-2}$ $387 \mathrm{~h}^{-1}$ calculated for montmorillonite (Begg et al., 2013).

388 The long-term (greater than $30 \mathrm{~d}$ ) sorption of $\mathrm{Pu}(\mathrm{V})$ to bentonite was also studied over an 389 initial concentration range of $10^{-7}-10^{-11} \mathrm{M}$ Pu. Samples were analyzed after 30, 120 and $300 \mathrm{~d}$. 
At 30 days, the isotherm appears linear on a log-log plot with slope of $0.92 \pm 0.03$ (Figure 3).

391 However, the slope of 0.92 indicates that sorption is, in fact, non-linear and appears to exhibit a

392 Freundlich behavior (i.e. $S=K_{f} C^{n}$ with $n=0.92$ ). However, as these data do not reflect an 393 equilibrium state and sorption is affected by surface mediated reduction rates, the apparent non394 linearity most likely reflects a concentration dependence on the surface mediated reduction of $395 \mathrm{Pu}(\mathrm{V})$. This is consistent with the findings of Hixon and Powell (2014) who observed a 396 concentration rate dependence for $\mathrm{Pu}(\mathrm{V})$ reduction on hematite between $10^{-8}$ and $10^{-6} \mathrm{M}$. At 120 $397 \mathrm{~d}$, the isotherm is truly linear with a log-log slope of $1.03 \pm 0.03$. Further, the position of the 398 isotherm has shifted between the two time points, indicating that sorption of $\mathrm{Pu}$ from the aqueous 399 phase has continued over the time period between $30 \mathrm{~d}$ and $120 \mathrm{~d}$. At $300 \mathrm{~d}$, the isotherm is 400 linear $(1.02 \pm 0.001)$, with a further small shift in position relative to the $120 \mathrm{~d}$ isotherm.

The $\mathrm{Pu}(\mathrm{V})$ sorption data for $30 \mathrm{~d}$ and $300 \mathrm{~d}$ is compared to the $120 \mathrm{~d} \mathrm{Pu(IV)}$ sorption data in

402 Figure 4. Over the course of the experiment, the position of the $\mathrm{Pu}(\mathrm{V})$ sorption data moves 403 towards the $120 \mathrm{~d} \mathrm{Pu(IV)}$ sorption data. This observation is consistent with the idea that 404 kinetically limited reduction of $\mathrm{Pu}(\mathrm{V})$ on the mineral surface is responsible for the slow, 405 continued uptake of $\mathrm{Pu}(\mathrm{V})$ (Begg et al., 2013). $\mathrm{Log} \mathrm{K}_{\mathrm{d}}$ values for $\mathrm{Pu}(\mathrm{V})$ sorption to bentonite 406 after 300 days were $4.42 \pm 0.03$. The similarity of the $K_{d}$ values of both $\mathrm{Pu}(\mathrm{IV})$ and $\mathrm{Pu}(\mathrm{V})$ over 407 these long timescales demonstrates a convergence of the sorption behavior of $\mathrm{Pu}$ on bentonite 408 regardless of initial oxidation state.

409 By assuming that the slow uptake of $\mathrm{Pu}$ from solution seen in the $\mathrm{Pu}(\mathrm{V})$ isotherm was due to 410 the slow reduction of $\mathrm{Pu}(\mathrm{V})$ on the clay surface, the data from the $30 \mathrm{~d}, 120 \mathrm{~d}$, and $300 \mathrm{~d}$ time 411 points were used to estimate the apparent reduction rate. By using these last three data points, we 412 hope to better isolate the reduction process from the early time sorption of $\mathrm{Pu}(\mathrm{V})(\mathrm{Begg}$ et al., 
413 2013). Apparent first order reduction rates were calculated from the slope of the plot of $\ln (\mathrm{C})$

414 versus time. The average surface normalized apparent reduction rate for these experiments was

$41510^{-5.3 \pm 1.3} \mathrm{~L} \mathrm{~m}^{-2} \mathrm{~h}^{-1}$. Interestingly, when the same calculation was applied to the $\mathrm{Pu}(\mathrm{IV}) \mathrm{data}$

416 collected at $10^{-10} \mathrm{M}$ for 67,100 and $120 \mathrm{~d}$, the calculated rate was $10^{-4.7 \pm 0.7} \mathrm{~L} \mathrm{~m}^{-2} \mathrm{~h}^{-1}$. The

417 similarity between the values further suggests that the long term uptake observed in $\mathrm{Pu}(\mathrm{IV})$

418 experiments was due to reduction of residual $\mathrm{Pu}(\mathrm{V})$ in solution.

419 The oxidation state of $\mathrm{Pu}$ in solution was monitored for bentonite experiments performed at $42010^{-10} \mathrm{M}$ and $10^{-8} \mathrm{M} \mathrm{Pu}(\mathrm{V})$ using $\mathrm{LaF}_{3}$ precipitation (SI Figure S5). In both experiments, the 421 percentage of $\mathrm{Pu}(\mathrm{V}) /(\mathrm{VI})$ in solution declined between 30 and 120 days. At $300 \mathrm{~d}$, the percent $422 \mathrm{Pu}(\mathrm{V}) /(\mathrm{VI})$ in solution was $\sim 33$ at both $10^{-10} \mathrm{M}$ and $10^{-8} \mathrm{M}$, respectively. In contrast, in mineral 423 free $\mathrm{Pu}(\mathrm{V})$ experiments, $\mathrm{LaF}_{3}$ analysis showed that the $\mathrm{Pu}$ remaining in solution after 300 days 424 was dominated by $\mathrm{Pu}(\mathrm{V}) /(\mathrm{VI})\left(96 \pm 10 \%\right.$ and $75 \pm 18 \%$ for experiments at $10^{-10}$ and $10^{-8} \mathrm{M}$, 425 respectively). This difference in oxidation state indicates that interaction of $\mathrm{Pu}(\mathrm{V})$ with mineral 426 surfaces results not only in surface mediated reduction of $\mathrm{Pu}(\mathrm{V})$ but also leads to a difference in 427 oxidation state distribution in solution. This change in the oxidation state of solution $\mathrm{Pu}$ in the 428 presence of bentonite indicates that a solid:solution sorption equilibrium is established with 429 respect to both $\mathrm{Pu}(\mathrm{V})$ and $\mathrm{Pu}(\mathrm{IV})$ under the present experimental conditions. This is in 430 accordance with the recently proposed model for $\mathrm{Pu}(\mathrm{V})$ oxidation state distribution in the 431 solid/aqueous phase following sorption on Savannah River sediments (Powell et al., 2014).

432 3.3 Desorption of Pu From Bentonite

433 A flow cell experiment was performed to investigate the desorption of $\mathrm{Pu}$ from bentonite. 434 Prior to desorption, $\mathrm{Pu}(\mathrm{IV})$ at an initial concentration of $3 \times 10^{-10} \mathrm{M}$ was equilibrated with $1 \mathrm{~g} \mathrm{~L}^{-1}$ 435 bentonite in $0.7 \mathrm{mM} \mathrm{NaHCO}_{3}, 5 \mathrm{mM} \mathrm{NaCl}$ buffer solution at $\mathrm{pH} 8$ for 21 days under aerobic 
436 conditions. After this period, the calculated $\log \mathrm{K}_{\mathrm{d}}$ for $\mathrm{Pu}(\mathrm{IV})$ sorption was 4.1, which is

437 consistent with the sorption behavior of the $\mathrm{Pu}(\mathrm{IV})$ isotherm experiment performed at $10^{-10} \mathrm{M}$

$438 \quad(4.4$ at $67 \mathrm{~d}, 4.8$ at $120 \mathrm{~d})$.

439 The desorption of $\mathrm{Pu}$ from bentonite is plotted in terms of the cumulative fraction of total $\mathrm{Pu}$ 440 desorbed in Figure 5. Also included in this plot are the data from a parallel experiment at $\mathrm{pH} 8$ 441 performed with SWy-1 Na-montmorillonite. Much (but not all) of the sharp increase in the 442 cumulative desorbed $\mathrm{Pu}$ between 0 and $\sim 2.5$ chamber volumes (cv) in both plots represents 443 removal of aqueous $\mathrm{Pu}$ remaining in solution following the sorption period. This $\mathrm{Pu}$ is displaced 444 from the flow cell over the course of several cv (i.e. tailing). Comparison of a theoretical non445 reactive tracer dilution curve under the initial flow conditions with the observed $\mathrm{Pu}$ 446 concentrations in the bentonite experiment shows that the two curves begin to deviate within 1.2 $447 \mathrm{cv}$ (SI Figure S6). The deviation demonstrates an excess of $\mathrm{Pu}$ in the effluent from that which 448 would be expected by dilution alone, indicating that $\mathrm{Pu}$ desorption from bentonite contributes 449 significantly to the overall Pu breakthrough after just one chamber volume.

450 Both the shape of the plots and the final amounts of Pu desorbed are very similar for FEBEX 451 bentonite and SWy-1 montmorillonite. This behavior is not unexpected in the context of the 452 similarity of $\mathrm{Pu}$ sorption behavior between bentonite and montmorillonite. This plot further 453 suggests that it is the montmorillonite component of the FEBEX bentonite that is controlling the 454 desorption behavior of $\mathrm{Pu}$ in this experiment. The slope of the cumulative desorption plot for 455 both bentonite and montmorillonite continues to rise over the duration of the experiment, 456 indicating that $\mathrm{Pu}$ is still being desorbed from the mineral surfaces at the termination of the flow 457 period. 
We calculated an apparent log $\mathrm{Kd}$ at the end of the flow cell experiment of 6.0 based on the

$459 \mathrm{Pu}$ concentration in the final effluent fraction, accounting for the net removal of $16.5 \%$ of the $\mathrm{Pu}$

460 from the system (Figure 5), and assuming no change in solid: solution ratio. This $\mathrm{K}_{\mathrm{d}}$ value is

461 much larger than the values in the $\mathrm{Pu}(\mathrm{IV})$ sorption experiments after $120 \mathrm{~d}$ equilibration (4.3 -

462 4.9). This indicates that on the timescale of the flow portion of the experiment (chamber

463 residence time $<1 \mathrm{~d}$ ) desorption of $\mathrm{Pu}$ appears to be rate limited. Following the cessation of the

$46412 \mathrm{~d}$ flow cell desorption experiment, the Pu-bentonite suspension was allowed to equilibrate

465 under no-flow conditions $\left(0.0 \mathrm{~mL} \mathrm{~min}^{-1}\right)$ for two months. After $60 \mathrm{~d}$, the $\log \mathrm{K}_{\mathrm{d}}$ was calculated to 466 be 4.8 , which is in good agreement with the $120 \mathrm{~d}$ sorption $\mathrm{K}_{\mathrm{d}}$ values. This similarity indicates

467 Pu-bentonite sorption reversibility over extended time periods. The slow approach to apparent 468 desorption equilibrium in these experiments (i.e. on timescales greater than $1 \mathrm{~d}$ ) is consistent 469 with previous work looking at $\mathrm{Pu}$ desorption from montmorillonite, bentonite colloids and 470 argillites (Huber et al., 2011; Latrille et al., 2006; Lu et al., 2003). The slow desorption kinetics 471 observed here highlight the need to consider both desorption rates and desorption equilibrium 472 conditions when predicting Pu transport.

473 Oxidation state analysis using $\mathrm{LaF}_{3}$ precipitation was performed on flow cell effluent during 474 the flow period, after remnant aqueous $\mathrm{Pu}$ from the sorption step had been removed from the 475 cell. The analysis indicated that the desorbed $\mathrm{Pu}$ was predominantly in the $\mathrm{Pu}(\mathrm{V}) /(\mathrm{VI})$ oxidation 476 state $(90 \pm 10 \%)$. This would suggest that in the short term, desorption of $\mathrm{Pu}(\mathrm{V})$ from the mineral 477 surface is favored over $\mathrm{Pu}(\mathrm{IV})$. Further, given that $\mathrm{Pu}(\mathrm{IV})$ was initially adsorbed on the bentonite 478 and is expected to be favored on the mineral surface, this result also suggests that the oxidation 479 of $\mathrm{Pu}(\mathrm{IV})$ to $\mathrm{Pu}(\mathrm{V})$ is important for the desorption of $\mathrm{Pu}$. However we cannot verify this without 480 direct oxidation state analysis of $\mathrm{Pu}$ on the mineral surface. If $\mathrm{Pu}(\mathrm{IV})$ oxidation is involved in the 
481 desorption reaction, $\mathrm{Pu}$ desorption rates may be substantially lower under anoxic conditions

482 where $\mathrm{Pu}(\mathrm{IV})$ oxidation is inhibited. Such an inhibition may further exacerbate mineral-colloid

483 facilitated transport under anoxic repository conditions. Interestingly, oxidation state analysis of

484 the $\mathrm{Pu}$ supernatant after the 2 month post flow cell equilibration period indicated that the 485 aqueous $\mathrm{Pu}$ was predominantly $\mathrm{Pu}(\mathrm{IV})$. This suggests that changes in $\mathrm{Pu}$ oxidation state are 486 responsible for differences in short term and long term desorption behavior of $\mathrm{Pu}$ from bentonite.

\section{4. CONCLUSIONS}

488 We investigated the sorption behavior of $\mathrm{Pu}(\mathrm{IV})$ to FEBEX bentonite over the concentration 489 range $10^{-7}-10^{-16} \mathrm{M}$ to determine if $\mathrm{Pu}$ sorption behavior at concentrations used in typical 490 laboratory experiments $\left(10^{-7}-10^{-11} \mathrm{M}\right)$ was comparable to typical environmental concentrations $491\left(\leq 10^{-12} \mathrm{M}\right)$. On the timescale of months, the affinity of $\mathrm{Pu}(\mathrm{IV})$ for bentonite appears to be 492 independent of concentration. However, slight non-linear behavior suggests that 493 polymerization/precipitation reactions contribute to the apparent sorption at $\mathrm{Pu}(\mathrm{IV})$ 494 concentrations $\geq 10^{-8} \mathrm{M}$. The sorption behavior of $\mathrm{Pu}(\mathrm{IV})$ to FEBEX bentonite is very similar to 495 that previously observed for Pu(IV) sorption to colloidal SWy-1 Na-montmorillonite.

$496 \mathrm{Pu}(\mathrm{V})$ sorption to bentonite is also linear. However, $\mathrm{Pu}(\mathrm{V})$ sorption exhibits a much more 497 significant time-dependence. The time-dependence is indicative of rate limited reduction of $498 \mathrm{Pu}(\mathrm{V})$ on clay minerals. The reduction rate constants determined based on these data agree with 499 previously published reduction rates of $\mathrm{Pu}(\mathrm{V})$ on $\mathrm{SWy}-1$ montmorillonite. The favorable 500 comparison between $\mathrm{Pu}(\mathrm{IV})$ and $\mathrm{Pu}(\mathrm{V})$ behavior in the presence of FEBEX bentonite and $\mathrm{SWy}-1$

501 Na-montmorillonite highlights the dominant role of montorillonite phases in controlling $\mathrm{Pu}$ 502 sorption/desorption reactions on FEBEX bentonite. By extension, this also suggests that the 
accessory minerals in the bentonite do not significantly alter the sorption/desorption behavior of $\mathrm{Pu}$.

The kinetics of desorption are of key importance for predicting the mobility of $\mathrm{Pu}$ in 506 groundwater environments, especially if $\mathrm{Pu}$ is associated with colloidal mineral phases. The 507 observation that after 2 months of desorption the $K_{d}$ value was similar to the $K_{d}$ value observed 508 after $21 \mathrm{~d}$ sorption indicates rate-limited yet truly reversible $\mathrm{Pu}$ sorption under these 509 experimental conditions. These experiments were performed under aerobic conditions and $510 \mathrm{Pu}(\mathrm{IV})$ reoxidation appears to play an important role in the observed desorption behavior. 511 Aerobic conditions may not be present in all nuclear waste repository scenarios (e.g. Duro et al., 512 2014). As a result, future work should build on these results by examining Pu sorption/desorption 513 behavior across a wider range of geochemical conditions.

\section{ACKNOWLEDGEMENTS}

We thank P. Reimus (LANL) for providing the bentonite used in this work. We are grateful for the input of two anonymous reviewers and the editor, S.C. Sheppard which greatly improved the

517 quality of this manuscript. This work was supported by the Used Fuel Disposition Campaign of 518 the Department of Energy's Nuclear Energy Program and the Subsurface Biogeochemical 519 Research Program of the U.S. Department of Energy's Office of Biological and Environmental 520 Research. Prepared by LLNL under Contract DE-AC52-07NA27344.

\section{REFERENCES}

Artinger, R., Schuessler, W., Schaefer, T., Kim, J.I., 2002. A kinetic study of Am(III)/humic colloid interactions. Environmental Science \& Technology 36, 4358-4363. Begg, J.D., Zavarin, M., Kersting, A.B., 2014. Plutonium desorption from mineral surfaces at environmental concentrations of hydrogen peroxide. Environmental Science \& Technology 48, 62016210.

Begg, J.D., Zavarin, M., Zhao, P., Tumey, S.J., Powell, B., Kersting, A.B., 2013. Pu(V) and Pu(IV) sorption to montmorillonite. Environmental Science \& Technology 47, 5146-5153. 
Choppin, G.R., 1991. Redox speciation of plutonium in natural waters. Journal of Radioanalytical and Nuclear Chemistry-Articles 147, 109-116.

Choppin, G.R., 2007. Actinide speciation in the environment. Journal of Radioanalytical and Nuclear Chemistry 273, 695-703. Hanford site. Journal of Contaminant Hydrology 76, 167-189.

Dozol, M., Hagemann, R., Hoffman, D.C., Adloff, J.P., Vongunten, H.R., Foos, J., Kasprzak, K.S., Liu, Y.F., Zvara, I., Ache, H.J., Das, H.A., Hagemann, R.J.C., Herrmann, G., Karol, P., Maenhaut, W., Nakahara, H., Sakanoue, M., Tetlow, J.A., Baro, G.B., Fardy, J.J., Benes, P., Roessler, K., Roth, E., Burger, K., Steinnes, E., Kostanski, M.J., Peisach, M., Liljenzin, J.O., Aras, N.K., Myasoedov, B.F., Holden, N.E., 1993. Radionuclide migration in groundwaters - Review of the behavior of actinides (Technical report) Pure and Applied Chemistry 65, 1081-1102.

Duro, L., Domènech, C., Grivé, M., Roman-Ross, G., Bruno, J., Källström, K., 2014. Assessment of the evolution of the redox conditions in a low and intermediate level nuclear waste repository (SFR1, Sweden). Applied Geochemistry 49, 192-205.

Dzombak, D.A., Morel, F.M.M., 1993. Surface complexation modeling: hydrous ferric oxide. WileyInterscience, New York, p. 393.

Efurd, D.W., Runde, W., Banar, J.C., Janecky, D.R., Kaszuba, J.P., Palmer, P.D., Roensch, F.R., Tait, C.D., 1998. Neptunium and plutonium solubilities in a Yucca Mountain groundwater. Environmental Science \& Technology 32, 3893-3900.

Fernandez, A.M., Baeyens, B., Bradbury, M., Rivas, P., 2004. Analysis of the porewater chemical composition of a Spanish compacted bentonite used in an engineered barrier. Physics and Chemistry of the Earth 29, 105-118.

Geckeis, H., Schafer, T., Hauser, W., Rabung, T., Missana, T., Degueldre, C., Mori, A., Eikenberg, J., Fierz, T., Alexander, W.R., 2004. Results of the colloid and radionuclide retention experiment (CRR) at the Grimsel Test Site (GTS), Switzerland - impact of reaction kinetics and speciation on radionuclide migration. Radiochimica Acta 92, 765-774.

Grauer, R., 1986. Bentonite as a backfill material in the high-level waste repository: Chemical aspects, EIR Bericht Nr. 576, Nagra Technical Report NTB 86-12E. Paul Scherrer Institut, Villigen, Switzerland and Nagra, Wettingen, Switzerland.

Grim, R.E., 1968. Clay mineralogy, 2nd ed. McGraw Hill.

Guillaumont, R., Fanghanel, T., Neck, V., Fuger, J., Palmer, D.A., Grenthe, I., Rand, M.H., 2003. Update on the chemical thermodynamics of uranium, neptunium, plutonium, americium, and technetium, in: Mompean, F.J., Illemassene, M., Domenech-Orti, C., Said, K.B. (Eds.), Chemical Thermodynamics. Elsevier, Amsterdam.

Guven, N., 1988. Smectites. Reviews in Mineralogy and Geochemistry 19, 497-559.

Guven, N., 1990. Longevity of bentonite as buffer material in a nuclear-waste repository. Engineering Geology 28, 233-247.

Hixon, A.E., Powell, B.A., 2014. Observed changes in the mechanism and rates of $\mathrm{Pu}(\mathrm{V})$ reduction on hematite as a function of total plutonium concentration. Environmental Science \& Technology 48, 92559262.

Huber, F., Kunze, P., Geckeis, H., Schafer, T., 2011. Sorption reversibility kinetics in the ternary system radionuclide-bentonite colloids/nanoparticles-granite fracture filling material. Applied Geochemistry 26, 2226-2237.

IAEA, 1995. Principles of Radioactive Waste Management, Safety Series IAEA, Vienna.

Icopini, G.A., Lack, J.G., Hersman, L.E., Neu, M.P., Boukhalfa, H., 2009. Plutonium(V/VI) reduction by the metal-reducing Bacteria Geobacter metallireducens GS-15 and Shewanella oneidensis MR-1. Applied and Environmental Microbiology 75, 3641-3647.

Kaplan, D.I., Powell, B.A., Duff, M.C., Demirkanli, D.I., Denham, M., Fjeld, R.A., Molz, F.J., 2007. Influence of sources on plutonium mobility and oxidation state transformations in vadose zone sediments. Environmental Science \& Technology 41, 7417-7423. 
Keeney-Kennicutt, W.L., Morse, J.W., 1985. The redox chemistry of $\mathrm{Pu}(\mathrm{V}) \mathrm{O}_{2}{ }^{+}$interaction with common mineral surfaces in dilute solutions and seawater. Geochimica Et Cosmochimica Acta 49, 2577-2588.

Kersting, A.B., Efurd, D.W., Finnegan, D.L., Rokop, D.J., Smith, D.K., Thompson, J.L., 1999. Migration of plutonium in ground water at the Nevada Test Site. Nature 397, 56-59.

Kersting, A.B., Zavarin, M., Powell, B.A., Moser, D., Carroll, S.A., Maxwell, R., Dai, Z., Williams, R., Tumey, S., Zhao, P., Tinnacher, R., Huang, P., Kips, R., Mason, H., Begg, J., Fisher, J., Simpkins, L., Zimmerman, T., Jablonski, J., Snow, M., 2011. LLNL SFA FY11 Program Management and Performance Report: Environmental Transport of Plutonium, pp. Medium: ED; Size: PDF-file: 32 pages; size: 32.32 Mbytes.

Kobashi, A., Choppin, G.R., 1988. A study of techniques for separating plutonium in different oxidation states. Radiochim. Acta 43, 211-215.

Latrille, C., Ly, J., Herbette, M., 2006. Retention of $\mathrm{Sn}(\mathrm{IV})$ and $\mathrm{Pu}(\mathrm{IV})$ onto four argillites from the Callovo-Oxfordian level at Bure (France) from eight equilibrated sedimentary waters. Radiochimica Acta 94, 421-427.

Lu, N.P., Reimus, P.W., Parker, G.R., Conca, J.L., Triay, I.R., 2003. Sorption kinetics and impact of temperature, ionic strength and colloid concentration on the adsorption of plutonium-239 by inorganic colloids. Radiochimica Acta 91, 713-720.

Lujaniene, G., Motiejunas, S., Sapolaite, J., 2007. Sorption of Cs, Pu and Am on clay minerals. Journal of Radioanalytical and Nuclear Chemistry 274, 345-353.

Marchetti, A.A., Brown, T.A., Cox, C.C., Hamilton, T.F., Martinelli, R.E., 2005. Accelerator mass spectrometry of actinides. Journal of Radioanalytical and Nuclear Chemistry 263, 483-487.

McCubbin, D., Leonard, K.S., 1996. Photochemical dissolution of radionuclides from marine sediments. Marine Chemistry 55, 399-408.

Missana, T., Alonso, U., Garcia-Gutierrez, M., Mingarro, M., 2008. Role of bentonite colloids on europium and plutonium migration in a granite fracture. Applied Geochemistry 23, 1484-1497.

Missana, T., Garcia-Gutierrez, M., 2007. Adsorption of bivalent ions (Ca(II), Sr(II) and $\mathrm{Co}(\mathrm{II})$ ) onto FEBEX bentonite. Physics and Chemistry of the Earth 32, 559-567.

Missana, T., Garcia-Gutierrez, M., Alonso, U., 2004. Kinetics and irreversibility of cesium and uranium sorption onto bentonite colloids in a deep granitic environment. Applied Clay Science 26, 137-150.

NAGRA, 2006. The CRR Final Project Report Series II: Supporting Laboratory Experiments with Radionuclides and Bentonite Colloids. Technical Report 03-02, in: Missana, T., Geckeis, H. (Eds.). Nagra, Wettingen, Switzerland

Neck, V., Altmaier, M., Seibert, A., Yun, J.I., Marquardt, C.M., Fanghanel, T., 2007. Solubility and redox reactions of $\mathrm{Pu}(\mathrm{IV})$ hydrous oxide: Evidence for the formation of $\mathrm{PuO}_{2+\mathrm{x}(\mathrm{s}, \text { hyd) }}$. Radiochimica Acta 95, 193-207.

Novikov, A.P., Kalmykov, S.N., Utsunomiya, S., Ewing, R.C., Horreard, F., Merkulov, A., Clark, S.B., Tkachev, V.V., Myasoedov, B.F., 2006. Colloid transport of plutonium in the far-field of the Mayak Production Association, Russia. Science 314, 638-641.

Orlandini, K.A., Penrose, W.R., Nelson, D.M., 1986. Pu(V) as the stable form of oxidized plutonium in natural waters. Marine Chemistry 18, 49-57.

Penrose, W.R., Polzer, W.L., Essington, E.H., Nelson, D.M., Orlandini, K.A., 1990. Mobility of plutonium and americium through a shallow aquifer in a semiarid region. Environmental Science \& Technology 24, 228-234.

Powell, B.A., Dai, Z.R., Zavarin, M., Zhao, P.H., Kersting, A.B., 2011a. Stabilization of plutonium nanocolloids by epitaxial distortion on mineral surfaces. Environmental Science \& Technology 45, 2698-2703. Powell, B.A., Fjeld, R.A., Kaplan, D.I., Coates, J.T., Serkiz, S.M., 2004. Pu(V)O ${ }_{2}^{+}$adsorption and reduction by synthetic magnetite $\left(\mathrm{Fe}_{3} \mathrm{O}_{4}\right)$. Environmental Science \& Technology 38, 6016-6024.

Powell, B.A., Fjeld, R.A., Kaplan, D.I., Coates, J.T., Serkiz, S.M., 2005. Pu(V)O ${ }_{2}{ }^{+}$adsorption and reduction by synthetic hematite and goethite. Environmental Science \& Technology 39, 2107-2114. 
Powell, B.A., Kaplan, D.I., Serkiz, S.M., Coates, J.T., Fjeld, R.A., 2014. Pu(V) transport through Savannah River Site soils - an evaluation of a conceptual model of surface- mediated reduction to $\mathrm{Pu}$ (IV). Journal of Environmental Radioactivity 131, 47-56.

Powell, B.A., Kersting, A.B., Zavarin, M., Zhao, P., 2011b. Development of a Composite NonElectrostatic Surface Complexation Model Describing Plutonium Sorption to Aluminosilicates. Lawrence Livermore National Laboratory, Livermore, California.

Romanchuk, A.Y., Kalmykov, S.N., Aliev, R.A., 2011. Plutonium sorption onto hematite colloids at femto- and nanomolar concentrations. Radiochimica Acta 99, 137-144.

Ross, C.S., Shannon, E.V., 1926. The minerals of bentonite and related clays and their physical properties. Journal of the American Ceramic Society 9, 77-96.

Sabodina, M.N., Kalmykov, S.N., Sapozhnikov, Y.A., Zakharova, E.V., 2006. Neptunium, plutonium and ${ }^{137} \mathrm{Cs}$ sorption by bentonite clays and their speciation in pore waters. Journal of Radioanalytical and Nuclear Chemistry 270, 349-355.

Sanchez, A.L., Murray, J.W., Sibley, T.H., 1985. The adsorption of plutonium IV and plutonium V on goethite. Geochimica Et Cosmochimica Acta 49, 2297-2307.

Santschi, P.H., Roberts, K.A., Guo, L.D., 2002. Organic nature of colloidal actinides transported in surface water environments. Environmental Science \& Technology 36, 3711-3719.

Schwenk-Ferrero, A., 2013. German spent nuclear fuel legacy: Characteristics and high-level waste management issues. Science and Technology of Nuclear Installations 2013, 11.

Silva, R.J., Nitsche, H., 1995. Actinide environmental chemistry. Radiochimica Acta 70-1, 377-396. Snow, M.S., Zhao, P.H., Dai, Z.R., Kersting, A.B., Zavarin, M., 2013. Neptunium(V) sorption to goethite at attomolar to micromolar concentrations using radiometric methods. Journal of Colloid and Interface Science 390, 176-182.

Tinnacher, R.M., Zavarin, M., Powell, B.A., Kersting, A.B., 2011. Kinetics of neptunium(V) sorption and desorption on goethite: An experimental and modeling study. Geochimica Et Cosmochimica Acta 75, 6584-6599.

Vaniman, D., Furlano, A., Chipera, S., Thompson, J., Triay, I., 1995. Microautoradiography in studies of $\mathrm{Pu}(\mathrm{V})$ sorption by trace and fracture minerals in tuff. MRS Proceedings 412, 639-646.

Zavarin, M., Powell, B.A., Bourbin, M., Zhao, P.H., Kersting, A.B., 2012. $\mathrm{Np}(\mathrm{V})$ and $\mathrm{Pu}(\mathrm{V})$ ion exchange and surface-mediated reduction mechanisms on montmorillonite. Environ Sci Technol 46, 2692-2698.

Zhao, P.H., Zavarin, M., Leif, R.N., Powell, B.A., Singleton, M.J., Lindvall, R.E., Kersting, A.B., 2011. Mobilization of actinides by dissolved organic compounds at the Nevada Test Site. Applied Geochemistry 26, 308-318. 


\section{LIST OF FIGURE CAPTIONS}

Figure 1. $120 \mathrm{~d} \mathrm{Pu}(\mathrm{IV})$ sorption isotherm for FEBEX bentonite $\left(1 \mathrm{~g} \mathrm{~L}^{-1}\right)$ in $0.7 \mathrm{mM} \mathrm{NaHCO}_{3}, 5$ $\mathrm{mM} \mathrm{NaCl}$ buffer solution at $\mathrm{pH} 8$ (open black diamonds). Inset shows time series data for experiments at $10^{-7}$ and $10^{-10} \mathrm{M}$ initial $\mathrm{Pu}(\mathrm{IV})$ to indicate apparent adsorption equilibrium at 120 d. Also shown are data for $30 \mathrm{~d} \mathrm{Pu}(\mathrm{IV})$ adsorption isotherm for SWy-1 Na-montmorillonite $(1 \mathrm{~g}$ $\mathrm{L}^{-1}$ ) in $0.7 \mathrm{mM} \mathrm{NaHCO}_{3}, 5 \mathrm{mM} \mathrm{NaCl}$ buffer solution at $\mathrm{pH} 8$ (closed black diamonds) (Begg et al., 2013). Lines are shown to guide the eye only. Blue shaded area represents expected concentration for Pu(IV) colloid formation (Neck et al., 2007). Error bars, based on LSC counting uncertainties $(1 \sigma)$ for bentonite experiments and $1 \sigma$ for quadruplicate montmorillonite experiments, are within range of the symbols used.

Figure 2. Sorption of $\mathrm{Pu}(\mathrm{V})$ to FEBEX bentonite $\left(1 \mathrm{~g} \mathrm{~L}^{-1}\right.$; open red triangles $)$ and $\mathrm{SWy}-1 \mathrm{Na}-$ montmorillonite $\left(1 \mathrm{~g} \mathrm{~L}^{-1}\right.$; closed red triangles) plotted as percentage of $\mathrm{Pu}$ removed from solution vs time. Initial $\mathrm{Pu}$ concentrations were $10^{-10} \mathrm{M}$ for bentonite and $10^{-9} \mathrm{M}$ for montmorillonite. Error bars are based on $1 \sigma$ for triplicate bentonite experiments and $1 \sigma$ for quadruplicate montmorillonite experiments and where not visible are within range of symbols used.

Figure 3. $\mathrm{Pu}(\mathrm{V})$ sorption isotherm for FEBEX bentonite $\left(1 \mathrm{~g} \mathrm{~L}^{-1}\right)$ in $0.7 \mathrm{mM} \mathrm{NaHCO}, 5 \mathrm{mM}$ $\mathrm{NaCl}$ buffer solution at $\mathrm{pH}$ 8. Different symbols represent sampling at different time points: $30 \mathrm{~d}$ (open red triangles), $120 \mathrm{~d}$ (open blue triangles), $300 \mathrm{~d}$ (open green triangles). Lines are to guide the eye only. Error bars based on LSC counting uncertainties $(1 \sigma)$ are within range of symbols used.

Figure 4. Sorption of $\mathrm{Pu}(\mathrm{V})$ to FEBEX bentonite $\left(1 \mathrm{~g} \mathrm{~L}^{-1}, \mathrm{pH} 8\right)$ at $30 \mathrm{~d}$ (open red triangles) and $300 \mathrm{~d}$ (open green triangles), compared with $\mathrm{Pu}(\mathrm{IV})$ sorption to FEBEX bentonite $\left(1 \mathrm{~g} \mathrm{~L}^{-1}, \mathrm{pH}\right.$ 8) at $120 \mathrm{~d}$ (open black diamonds). Lines are to guide the eye only. Error bars based on LSC counting uncertainties $(1 \sigma)$ are within range of symbols used. 
Figure 5. Cumulative fraction of $\mathrm{Pu}$ removed from bentonite (open black diamonds) and montmorillonite (closed black diamonds) for the flow cell experiments. Error bars based on LSC counting uncertainties $(1 \sigma)$ are within range of symbols used. 


\section{FIGURES}

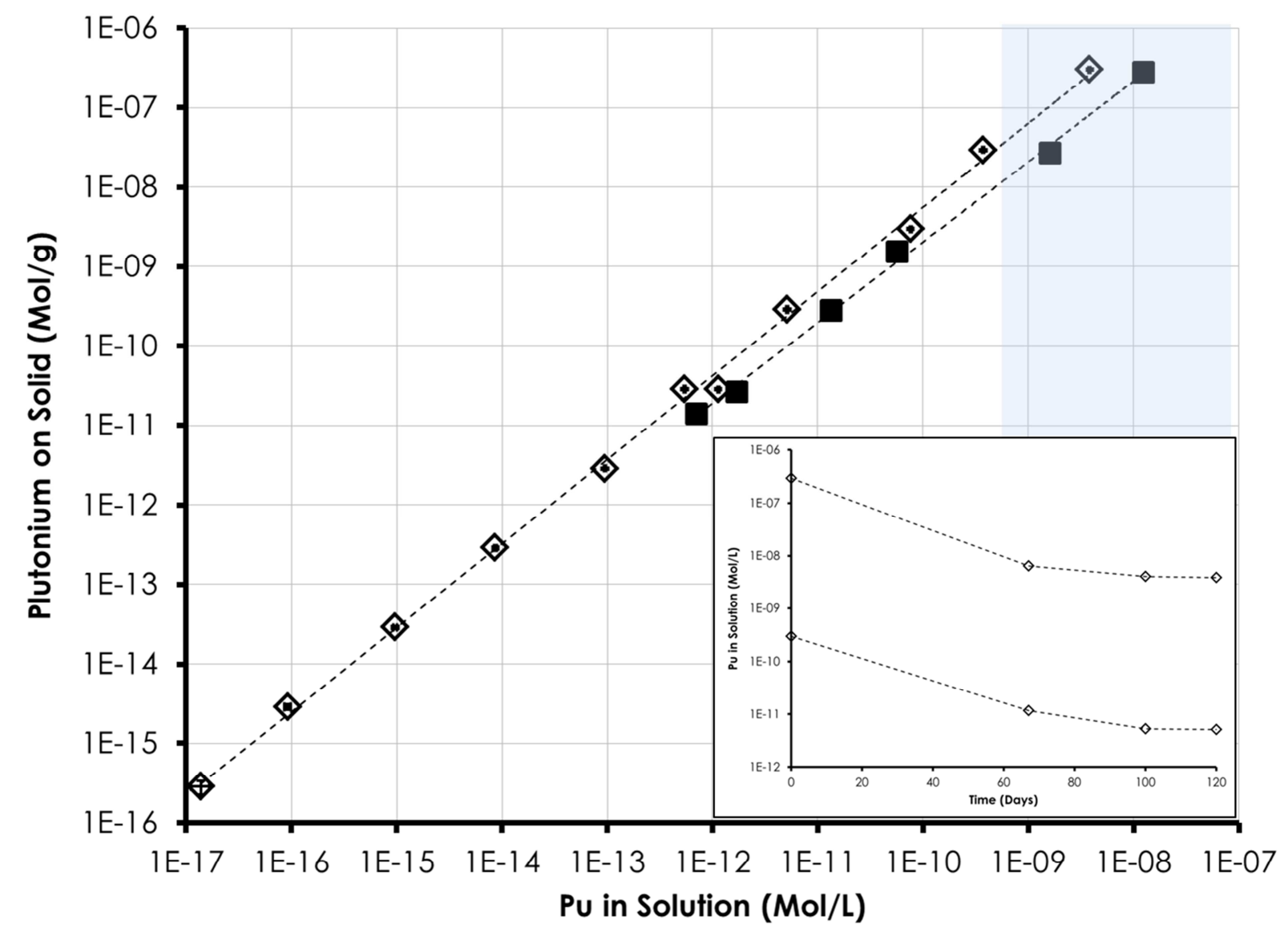

Figure 1 


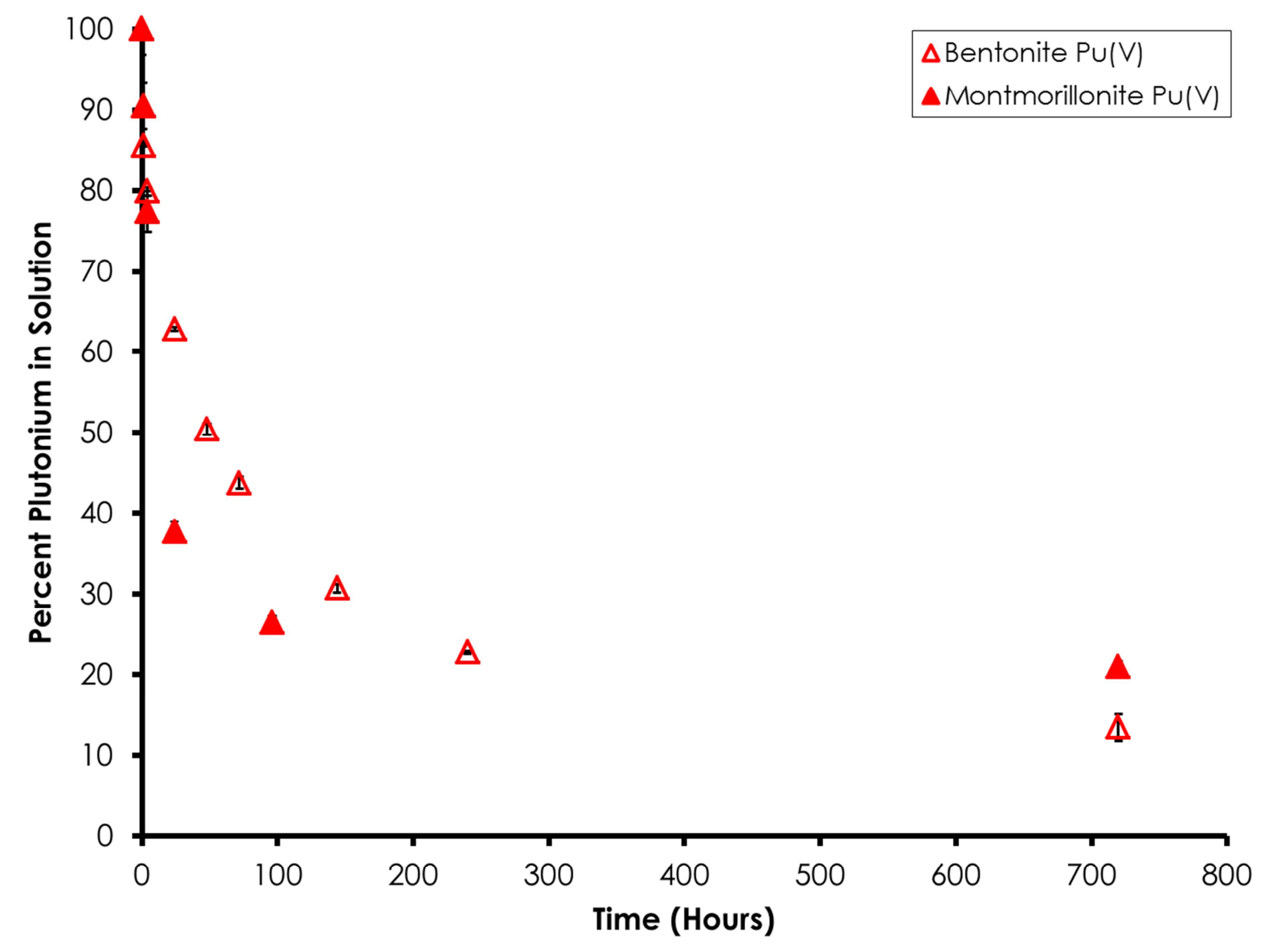

Figure 2 


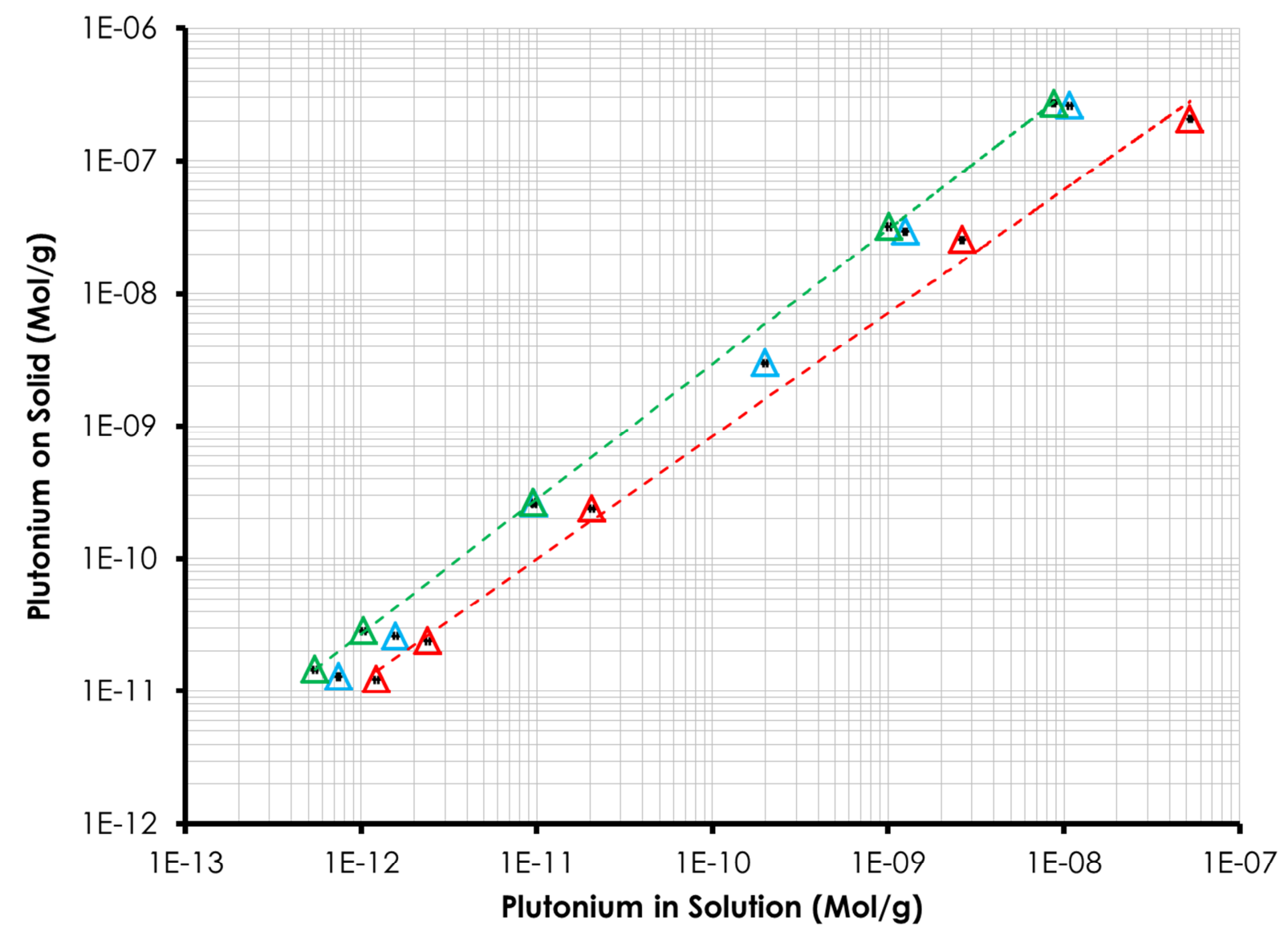

Figure 3 


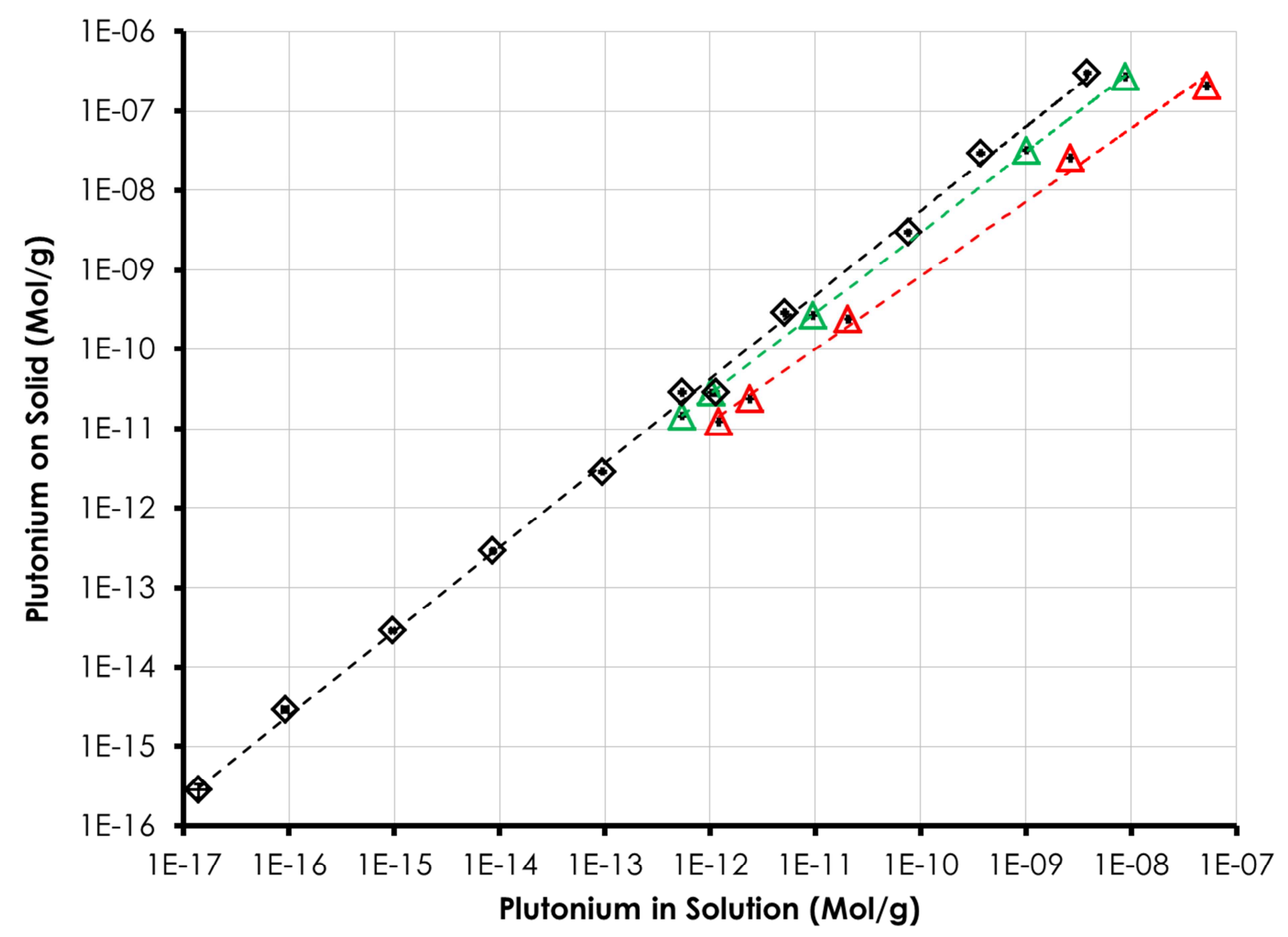

Figure 4 


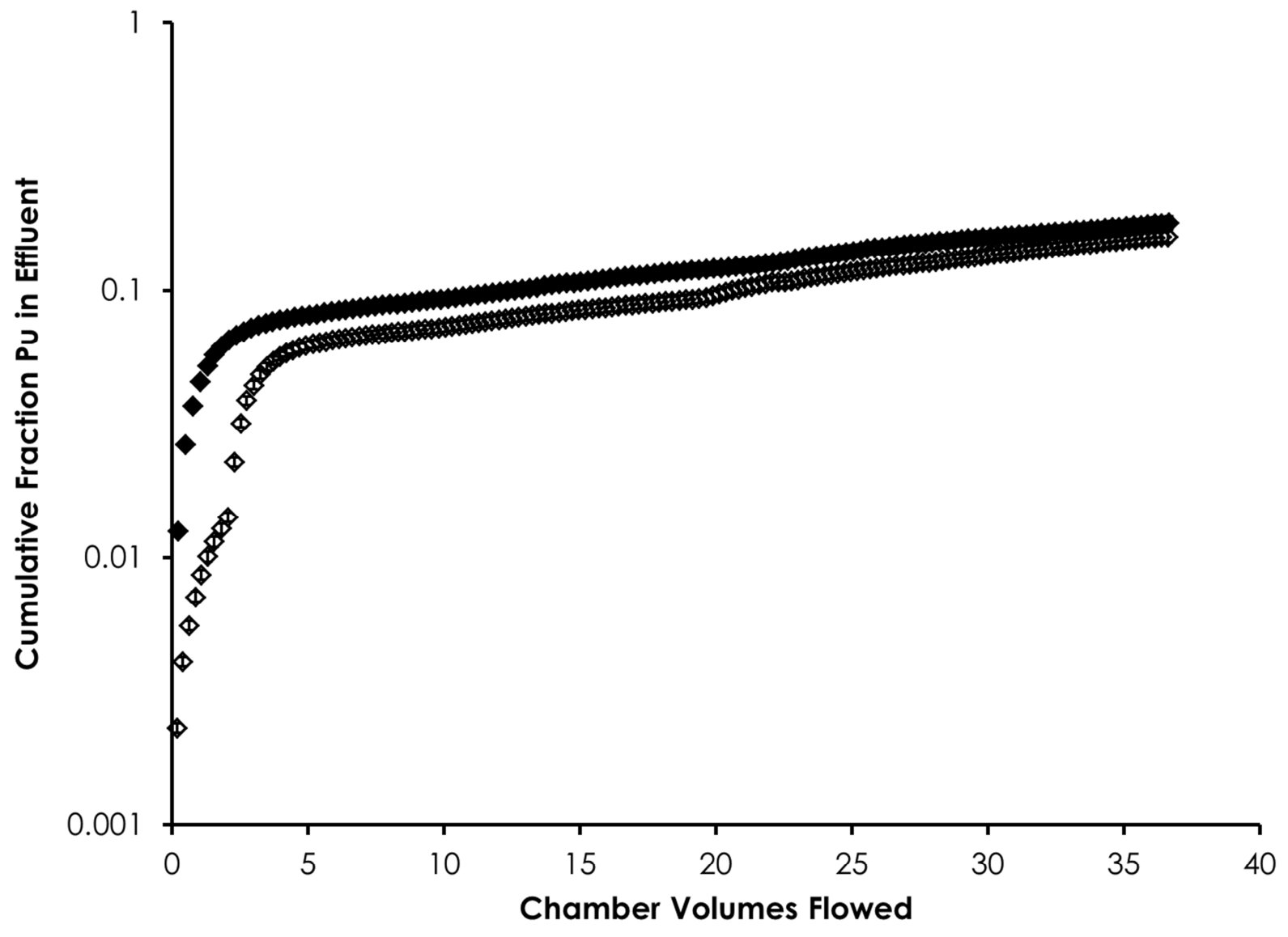

Figure 5 